\title{
The Effects of Marketing Mix to Buying Interest and Their Implication toward the Decision of Choosing Private Higher Education
}

\author{
Oyon Saryono, Nana Darna, Mujaddid Faruk \\ Fakultas Ekonomi Universitas Galuh \\ Ciamis, Indonesia \\ nanadarna@unigal.ac.id
}

\begin{abstract}
The upcoming implementation of ASEAN Economic Community is predicted to generate new trend of competition among educational institutions in Indonesia. The growth of private higher education has significantly increased since the issuance of UU No. 22 of 1999 on Regional government, so To survive, consequently, any private higher education should have competitive outstanding points determined by the right implementation of marketing mix. The objective of this research is to find out the effects of service marketing mix to buying interest and their implication toward the decision of choosing private higher education. The method of research we used in this research was descriptive correlational method by using SEM model. This research was conducted in Priangan Timur (Eastern parts of West Java). The result of this research indicates that marketing mix to buying interest has resulted in positive and significant effects; whereas, the effects of buying interest toward the decision of buying also have shown less value; in addition, the direct effects of marketing mix toward buying was positive and significant. The most dominant element of marketing mix concerning buying interest and the decision of buying was the element of human resource and site.
\end{abstract}

Keywords-decision, interest, marketing mix, higher education

\section{INTRODUCTION}

Since the program of Asean Economic Community (AEC) was put into effect in December of 2015, besides enabling wide opportunities, it has generated anxiety among educational institutions in Indonesia, especially private Higher Education. It is predicted that it will bring about tighter competition, especially by the tendency of new competitors from other countries of Asean to come; whereas, ongoing rivalry has occurred since the issuance of Regulation no. 22 of 1999 on Regional Government, in which every regency makes efforts to establish higher education in their region to provide easy access for the local people to study until higher education level for the sake of Human Development Index (IPM). The side effect of building higher education in every regency is the fact that some private higher education, especially located in big towns, failed to keep abreast of current competition; as a result, they have to be merged with other entities, even closed.

The growth of private higher education in the scope of Kopertis Wilayah IV (Coordination of Private higher education Zone IV) has performed to be one of the most rapid development in Indonesia. At present, it is noted that there are 502 high level of educational entities comprising university, institute, college, academy and polytech (Directory of Kopertis Wilayah IV of 2015). 46 of them are located in Priangan Timur (eastern parts of West Java).

The distribution of students in 46 higher education in Priangan Timur is not evenly spread. We may see some higher education with a lot of students, and the others with less ones. The rate of new entrance to them is also not the same, with increasing or decreasing trend. (Directory of Kopertis Wilayah IV of 2015)

To be able to survive, private higher educations are required to have competitive superiority since it is the prominent factor to win the business competition. The competitive superiority of higher education is determined partly by service marketing mix consisting of 1) product; 2) location; 3) price; 4) promotion; 5) human resource; 6) physical appearance; 7) Process. [6]

1) Product is something to offer to market to notice, to possess, to use or to consume for the sake of satisfying desire and fulfilling's need. Product covers physical object, service, people, site, organization and idea. [4]. 2) Price /tarrif is a state of expenses to spend by buyers to get product/ service provided by a business entity. It is the only element of marketing mix which results in income, while the others need expenses [5] 3) Location is a venue in which a company operates or a site where a company runs the business to make product and provide service that puts its economical aspect into priority. [1], 4) Promotion; elements of promotion consist of; advertising, face-to-face selling, selling promotion, dan publication performed by a company in the effort of providing customers with product knowledge, so they are triggered to make up their mind to buy. 5) People; All components of human resource that take part in providing service and affecting buying perception. [8], 6) physical evidence; physical environment in which service is provided and company and its customers interact as well as every tangible component that facilitate appearance or the communication on service [7] Elements of physical evidence cover all aspects of physical facilities belonging to a service organization that 
consist of exterior and interior attributes as well as other physical ones. 7). Process; Procedure, mechanism and flow of service delivery activity. [8]

The motive of prospective students to select their learning higher education is affected by motivation, perception and personal preference which deal with age, income, position, education, personality, attitude toward risk, and custom [5]

The decision of selecting or that of buying is usually made by a consumer after a series of process of making decision of buying. This procedure is influenced by five roles of people's in making the decision of purchasing, i.e. initiator, effect giver, decision maker, buyer and user [5]. The decision making also passes through steps of decision making process covering: identifying problem, seeking for information, performing alternative evaluation, making decision and acting after buying. [5].

\section{MethodS}

The research method used is quantitative method for examine the hypothesis by using parametric statistic with SEM analysis. The technique of collecting data was via questionnaires and observation. The subject of this research is students of private higher education (PTS) based in Wilayah Priangan Timur (Eastern parts of West Java. The variables observed are the seven components of marketing mix, i.e. product, location, promotion, human resource, process and physical evidence. The other variables that were controlled and measured are buying interest and the decision of buying/ selecting. The primary data was gathered through field research by distributing questionnaires to some learning students in private higher education, while the secondary was collected from literary study and review on policy, such as learning regulations, literary books, scientific journals, newspaper, scientific magazine, seminar booklet and relevant information via internet. Besides, the source of data was derived from related institutions and other literary work that have something to do with variables observed and measured in this research. The population is the students ranging from the first semester to the seventh semester of some private higher education in Priangan Timur. The number of students spread in 4 regencies and 2 towns of Priangan Timur is 45.766 people. The sample was taken by using the formula of Solving with significant standard $\alpha=0,05$ amounted to 396,53 rounded to 397 students.

\section{RESULT AND DISCUSSION}

The result of descriptive analysis review are as follows: due to each variable, it can be said that all respondents to the questionnaires of this research concerning variables of marketing mix, buying interest and the decision of buying/ selecting show average value above 3 (three). Variable of marketing mix dominantly falls into the category of good, buying interest comes to that of less, and the decision of buying/ selecting goes to that of good/ agree.

Bided on the student's perception, the result of analysis and review of marketing mix variables is good. The most dominant sub-variable is place/ location. The least is physical evidence. On the contrary, the calculation of AMOS shows that the most dominant is human resources, and the least is human resources, and the least is location.

The result of analysis and review on buying interest also indicate that they are less interested. The most dominant subvariable is trust, not perceptions shown by AMOS. The least important variables, due to their perception and AMOS, are desire and lifestyle.

The result of analysis and review on variable of the decision of buying/ selecting shown by students of private higher education in the area of Priangan Timur is agree. Of five sub-variable of buying/selecting decision, the most dominant due to their perception is product knowledge, and determination based on AMOS. The least important due to both sides is other's influence.

The hypothesis of the result of this research is discussed as follows:

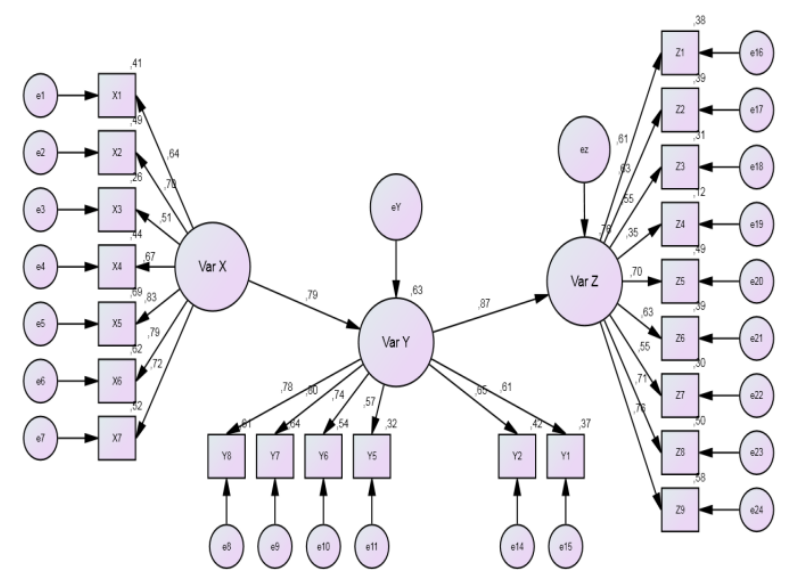

Fig. 1.

The result of the first hypothesis testing shows that marketing mix has positive and strong relation with buying interest, with the index of 0.79 . It is in line with what Simamora says that: " marketing is managerial and social process in which individuals and groups get what they want and need through creation, offer and exchange of product that shares value with another or other group." [9]

The result of the second hypothesis testing proves that buying interest affect the decision of buying simultaneously. The effect of buying interest to the decision of buying is positive and strong as much as $87 \%$. It is in line with the opinion of As 'ad who says that:" Interest is a state of attitude that makes someone take pleasure with a certain object, situation or idea. It is also the source of motivation that will lead someone to perform an action." [2]

The result of the third hypothesis testing proves that marketing mix has an influence toward the decision of buying. The indirect effect of buying interest to the decision of buying is positive, $69 \%$.It is in accordance with the opinion of Ciptono who states that: "Marketing strategy is a fundamental tool which is designed to achieve corporate objective by 
simultaneously improving the competitor's superiority through market access and marketing program performed to serve the target market." [3]

\section{CONCLUSions}

Of the result of hypothesis testing and its discussion, it can be concluded that marketing mix has something to do with buying interest positively and significantly. Buying interest positively and significantly affects the decision of buying. Marketing mix has direct influence to the decision of buying in the same way. The most influential marketing mix element is human resource and strategic location. It indicates that marketing mix will influence the decision of buying/ selecting a certain private higher education as a learning institution.

\section{REFERENCES}

[1] Alma, Buchari 2003, Pemasaran Strategik Jasa Pendidikan, Bandung :Alfabeta.

[2] As'ad, 1995, Prosedur Penelitian Suatu Pendekatan Praktek, Edisi Revisi, Jakarta: Rineka Cipta.

[3] Ciptono, Fandi, 2006, Manajemen Jasa, ANDI Offset, Yogyakarta.

[4] Kotler, Philip \& Armstrong, 2001, Principles of Marketing, 6th ed. Prenctice-Hall International Inc., New Jersey.

[5] Kotler, Phillip, 2003, Marketing Management, eleventh edition, Prentice Hall, New Jersey.

[6] Kotler, Philip, Kevin, Lane, Keller, 2009, Marketing Management, 13rd edition, Prentice Hall, Singapore

[7] Yazid, 2003, Pemasaran Jasa, Edisi Kedua, Ekonisia, UII, Yogyakarta

[8] Zeitmal, A., Valarie dan Mary Joe Bitner, 2000, Service Marketing Integrating Customer Focus The Firm, USA :Mc-Graw- Hill.

[9] Simamora, Bilson, 2007, Re Marketing For Bussiness Recovery, Jakarta, PT Gramedia Pustaka Utama.

[10] Web Site: http://www.kopertis4.co.id

[11] PeraturanPemerintah: PP No. 22 tahun 2009, TentangPemerintah Daerah 